University of Nebraska - Lincoln

DigitalCommons@University of Nebraska - Lincoln

Faculty Publications from the Harold W. Manter Laboratory of Parasitology

6-1983

\title{
Organization of Sporulated Oocysts of Eimeria funduli in the Gulf Killifish, Fundulus grandis
}

\author{
William E. Hawkins \\ Gulf Coast Research Laboratory, William.Hawkins@usm.edu \\ John W. Fournie \\ United States Environmental Protection Agency, fournie.john@epa.gov \\ Robin M. Overstreet \\ Gulf Coast Research Laboratory, robin.overstreet@usm.edu
}

Follow this and additional works at: https://digitalcommons.unl.edu/parasitologyfacpubs

Part of the Parasitology Commons

\begin{abstract}
Hawkins, William E.; Fournie, John W.; and Overstreet, Robin M., "Organization of Sporulated Oocysts of Eimeria funduli in the Gulf Killifish, Fundulus grandis" (1983). Faculty Publications from the Harold W. Manter Laboratory of Parasitology. 470.

https://digitalcommons.unl.edu/parasitologyfacpubs/470
\end{abstract}

This Article is brought to you for free and open access by the Parasitology, Harold W. Manter Laboratory of at DigitalCommons@University of Nebraska - Lincoln. It has been accepted for inclusion in Faculty Publications from the Harold W. Manter Laboratory of Parasitology by an authorized administrator of DigitalCommons@University of Nebraska - Lincoln. 


\title{
ORGANIZATION OF SPORULATED OOCYSTS OF EIMERIA FUNDULI IN THE GULF KILLIFISH, FUNDULUS GRANDIS
}

\author{
William E. Hawkins, John W. Fournie, and Robin M. Overstreet \\ Gulf Coast Research Laboratory, Ocean Springs, Mississippi 39564
}

ABSTRACT: Oocysts of Eimeria funduli were studied by transmission electron microscopy in naturally-infected livers of the Gulf killifish, Fundulus grandis. Tissues were cryo-processed because membranous structures in the oocyst appear to hinder routine fixation and embedment. The oocyst wall (about $25 \mathrm{~nm}$ thick) was adjacent to the host cell and consisted of an outer membrane that limited the host cell cytoplasm and an inner membrane separated from the outer membrane by a narrow space. In some specimens, dense material was applied to the inner face of the inner membrane. Individual sporocysts were surrounded by a membranous "veil" (about 25 $\mathrm{nm}$ thick) that consisted of two unit membranes. Sporopodia, projections of the sporocyst wall, supported the veil. The sporocyst wall (130-150 nm thick) consisted of two layers, a thin electron-lucent outer layer (about $10 \mathrm{~nm}$ thick) and a thick electron dense inner layer (about $130 \mathrm{~nm}$ thick). Depending on the plane of section, the inner layer had transverse striations with periods of 3 to $4 \mathrm{~nm}$ or 12 to $15 \mathrm{~nm}$. A narrow fissure, broadest at the anterior pole of the sporocyst, extended about one-third the length of the sporocyst wall. The posterior pole of the sporocyst was characterized by a bulbous swelling. Although this swelling resembled a Stieda body in light microscopic preparations, ultrastructurally, the swelling was a knoblike thickening in the sporocyst wall and did not plug a gap in this wall.

Compared with eimerians in terrestrial hosts, piscine eimerians have received little attention despite their possible importance in coccidian evolution and systematics (Desser, 1981; Overstreet, 1981) and in the health of commercially important fishes (Dyková and Lom, 1981; Overstreet, 1981). In these coccidians, the oocyst represents the most commonly encountered life cycle stage and the feature most frequently used to separate species. The ultrastructure of piscine coccidian oocysts, however, has been studied rarely.

In the present study, oocysts of Eimeria funduli Duszynski, Solangi, and Overstreet, 1979, were examined by transmission electron microscopy (TEM) in the naturally-infected Gulf killifish, Fundulus grandis Baird and Girard. Eimeria funduli primarily infects hepatocytes of killifishes, requires the grass shrimp Palaemonetes pugio Holthuis to complete its life cycle, and sporulates within host tissues (Solangi and Overstreet, 1980). Duszynski et al. (1979) described some ultrastructural features of $E$. funduli oocysts isolated by sugar flotation from homogenized tissues. To preserve in situ relationships of oocysts and at the same time overcome the resistance of oocysts to fixation and embedment, we cryo-processed infected livers and then fixed and embedded the tissues for rou-

Received 19 April 1982; revised 9 August 1982; accepted 20 October 1982. tine TEM. This study reports that $E$. funduli lacks a true oocyst wall, that the sporocyst lacks a Stieda body, and that the sporocyst wall has a narrow fissure through which sporozoites probably excyst.

\section{MATERIALS AND METHODS}

Naturally-infected $F$. grandis were collected in minnow traps from Halstead Bayou in Ocean Springs, Mississippi. After removing livers, we squashed fresh preparations between glass slides to confirm the presence of sporulated oocysts. In initial stages of the study, oocyst-containing livers were minced with a razor blade, fixed in $0.1 \mathrm{M}$ phosphate-buffered $3 \%$ glutaraldehyde for 1 to $3 \mathrm{hr}$, rinsed $1 \mathrm{hr}$ to overnight in phosphate buffer, postfixed in phosphate-buffered $1 \%$ osmium tetroxide for $2 \mathrm{hr}$, rinsed briefly in buffer, and dehydrated in a graded series of ethanol. Following treatment with propylene oxide, tissues were embedded in Embed (Epon) 812.

Because of resistance of the oocysts to fixation and embedment, we employed a modification of the double sectioning technique of Birch-Andersen et al. (1976). Oocyst-containing livers, mounted with Ames O.C.T. embedding compound on a metal chuck and frozen with liquified carbon dioxide, were minced with a single-edged razor blade that had been cooled with carbon dioxide and held with a pair of locking pliers. Minced tissues were allowed to thaw in $0.1 \mathrm{M}$ phosphate-buffered $3 \%$ glutaraldehyde and then fixed in the same solution for 1 to $3 \mathrm{hr}$. Tissues were subsequently processed as described above. To find suitable oocysts for thin sectioning, thick (1-2 $\mu \mathrm{m})$ sections were cut with an LKB Ultratome, mounted on glass slides, and stained with toluidine blue. Thin sections were cut with a diamond knife, mounted on uncoated, copper grids, stained with uranyl acetate and lead citrate, and examined in a Siemens Elmiskop 1A electron microscope. 


\section{RESULTS}

In squash preparations, most sporocysts and sporozoites appeared fully developed. Sporocysts usually collapsed in tissues processed by conventional techniques, probably because of poor infiltration of embedding medium. However, cryo-processing gave much better results. Whereas some sporocysts collapsed, many sporocysts, as well as host cells and noninfected liver parenchyma, were preserved satisfactorily. In epoxy-embedded thick sections, oocysts appeared spherical (about $21 \mu \mathrm{m}$ in diameter), with the oocyst wall usually abutting the host cell. However, the oocyst wall was often torn away from the host cell (Fig. 1). In some sporocysts with uncollapsed walls, the sporozoites appeared poorly preserved and shrunken, whereas in others the sporozoites were well-preserved and completely filled the sporocyst. Sporocysts with uncollapsed walls were ovoid (about $7 \mu \mathrm{m} \times 4 \mu \mathrm{m}$ ) and contained two sporozoites. A bulge occurred at the posterior pole of the sporocyst (Figs. 1, 2). This bulge resembled a Stieda body but, as described below, it did not have the ultrastructural characteristics of a true Stieda body. Depending on the plane of section, the posterior pole appeared either sharply pointed (Figs. 1, 2) or somewhat rounded (Fig. 2). The anterior end of the sporocyst was rounded, regardless of the plane of section (Figs. 1, 2). Projections of the sporocyst wall, the sporopodia, appeared to support a thin membrane that approached the surface of the sporocyst at the anterior end. In some views of sporocysts, a gap could be seen at the anterior pole (Fig. 1). In heavily infected livers, oocysts occurred in groups separated from uninfected liver by empty spaces or enclosed by a connective tissue capsule.

A thin ring of host cell cytoplasm completely surrounded each oocyst (Fig. 3). The host cell nucleus was compressed to conform to the spherical oocyst. The oocyst wall (about $25 \mathrm{~nm}$ thick) consisted of two unit membranes separated by a space adjacent to the host cell cytoplasm (Fig. 4). The outer membrane of the oocyst wall limited the host cell cytoplasm. A narrow space separated this membrane from the inner membrane which faced the oocyst contents. In some specimens, especially those processed by conventional techniques, dense material adhered to the oocyst side of the inner membrane, making it variably thicker than the outer membrane. In cryo-processed oocysts, however, the two mem- branes appeared nearly equal in thickness. Often, all three layers of the oocyst wall separated from the host cell, especially in routinely-processed tissues. The space between the inner membrane of the oocyst wall and the outer membrane of the sporocysts sometimes contained cellular debris or flocculent material. A three-layered membranous "veil" (about 10-20 nm thick) that consisted of two unit membranes surrounded each sporocyst (Figs. 3, 8, 9). Clear, homogeneous material that in fresh preparations appeared to fill the space between the veil and sporocyst wall did not appear in electron micrographs, apparently having been lost during preparation.

The sporocyst wall (130-150 nm thick) was regularly organized and uniform in thickness except where it gave rise to sporopodia and where it thickened at the posterior pole. The sporocyst wall consisted of a thick, electron-dense, inner layer (about 120-130 nm thick) lying beneath a thin, electron-lucent, outer layer (about $10 \mathrm{~nm}$ thick) that had a thin, superficial, electron-dense coating (Figs. 5, 6). In sections through the long axis of the sporocyst, the inner layer of the sporocyst wall appeared homogeneous. However, in some planes the inner layer had regular transverse striations with a period of 12 to $15 \mathrm{~nm}$ (Fig. 5). In other planes, transverse striations with a period of 3 to $4 \mathrm{~nm}$ could be seen (Fig. 6). Sporopodia, which had the same layers as the sporocyst wall, but which did not appear transversely striated, terminated in knoblike swellings (Fig. 7) that often apposed the sporocyst veil.

Various planes of section through the sporocyst revealed an opening or fissure that appeared to extend about one-third the length of the long axis of the sporocyst. Longitudinal sections perpendicular to the fissure showed that it was widest (about $0.3 \mu \mathrm{m}$ ) at the rounded, anterior pole of the sporocyst (Fig. 8). There, the fissure was bridged by the sporocyst veil which was attached to the outer lips of the sporocyst wall at the edges of the fissure and by a thin deposit of dense material that accumulated on the inner aspect of the fissure (Fig. 9). In other regions, sporopodia held the membranous veil away from the surface of the sporocyst. In cross-sections of the sporocyst, the fissure gradually narrowed to a suture often with some intervening dense material that appeared to be derived from sporocyst contents (Fig. 10). Superficially, a short projection of the sporocyst wall often indicated the location of the suture (Fig. 10). There was no evidence for a Stieda body or subStieda body associated with 


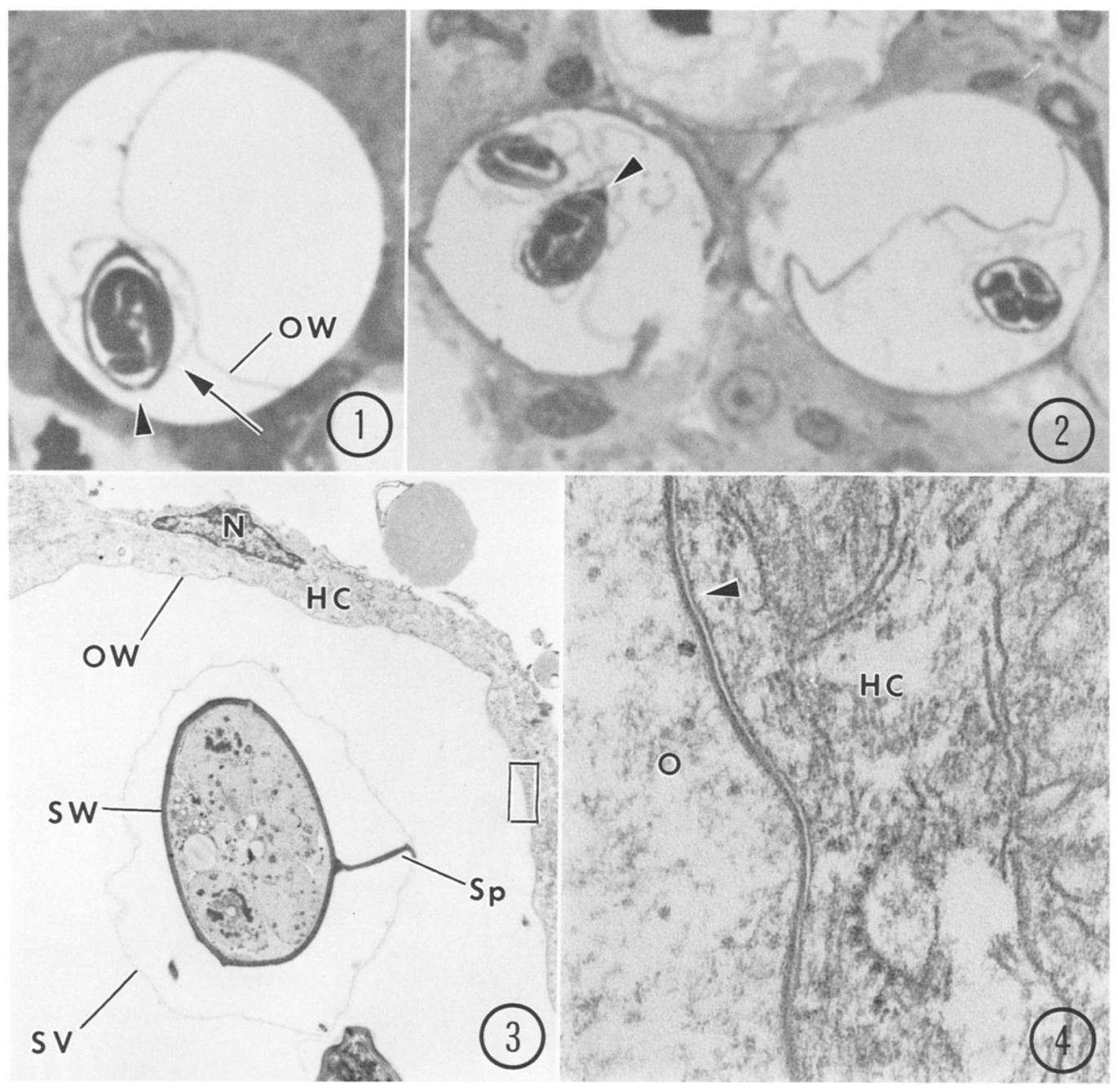

Figures 1-4. Eimeria funduli. 1. Light micrograph of epoxy-embedded $1-\mu \mathrm{m}$-thick section. Note gap in anterior pole (arrowhead). Oocyst wall (OW) is torn away from host cell cytoplasm. Sporocyst veil approaches surface of sporocyst at anterior pole (arrow). $\times 2,000$. 2. Light micrograph of epoxy-embedded 1 - $\mu \mathrm{m}$-thick section with two oocysts. Note "Stiedalike body" (arrowhead) at posterior pole of one sporocyst and cross-sections of sporozoites in sporocyst in right of figure. $\times 1,900$. 3. Low power TEM micrograph showing oocyst wall (OW), sporocyst veil (SV), and sporocyst wall (SW). Nucleus (N) belongs to a connective tissue cell adjacent to hepatocyte. An area comparable to that inside the rectangle is shown at higher magnification in Figure 4. Host cell (HC), sporopodium (Sp). $\times 6,100.4$. The oocyst wall is the boundary between the host cell (HC) cytoplasm and the oocyst $(\mathrm{O})$. Note some ribosomelike granules line the outer membrane of oocyst wall (arrowhead) whereas the inner membrane is smooth and somewhat thicker than outer membrane. $\times 92,100$.

the fissure. In some sporocysts, sporozoites protruded out of the anteriormost wide portion of the fissure.

In sections perpendicular to the fissure in the sporocyst wall, the bulge at the posterior pole appeared pointed (Figs. 8, 11). This bulge was mainly a thickening in the inner layer of the sporocyst wall (Fig. 11). Beneath this thickening, a layer of electron-dense granular material overlaid a layer of less electron-dense material. In sections that paralleled the fissure, the bulge appeared as a ridged structure (Fig. 12). Sporopodia occurred at the boundaries of the ridge (Figs. 12, 13).

We did not achieve optimal preservation of sporozoites, but nevertheless have provided some 


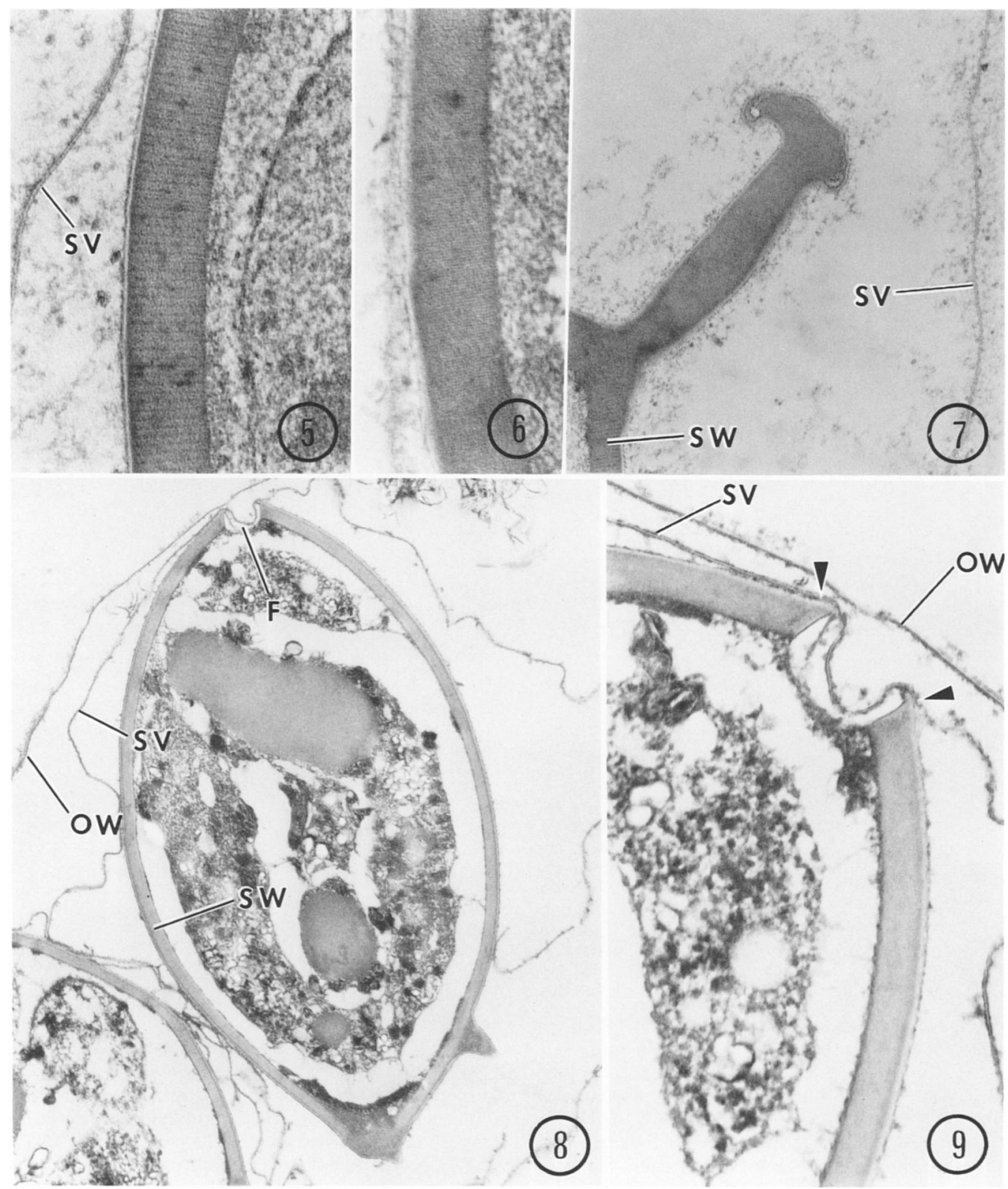

Figures 5-9. Eimeria funduli. 5. In some planes of section, sporocyst wall has transverse striations with 12- to 15 -nm period. Sporocyst veil (SV). $\times 66,700$. 6. Sporocyst wall showing periodic substructure of 3 to 4 nm. $\times 76,200$. 7. Sporopodium ending in knoblike swelling and having same layers as sporocyst wall (SW). Sporocyst veil (SV). $\times 3,500.8$. Sporocyst sectioned through fissure $(F)$ at anterior end. Note pointed thickening of sporocyst wall at posterior end. Oocyst wall (OW), sporocyst veil (SV), sporocyst wall (SW). $\times 13,500.9$. Higher magnification of anterior end of sporocyst in Figure 8. Sporocyst wall composed of outer, electron-lucent layer and inner, electron-dense area. Sporocyst veil (SV) attaches to sporocyst wall at margins of fissure (arrowheads). Note dense material applied to inner aspect of fissure. Oocyst wall (OW). $\times 47,600$.

information on their organization. The absence of certain organelles might be artifactual or might indicate that the sporozoites were not fully de- veloped. Each sporocyst contained two sporozoites curled around one another. A nucleolemma did not enclose the nuclear material (Fig. 13) 


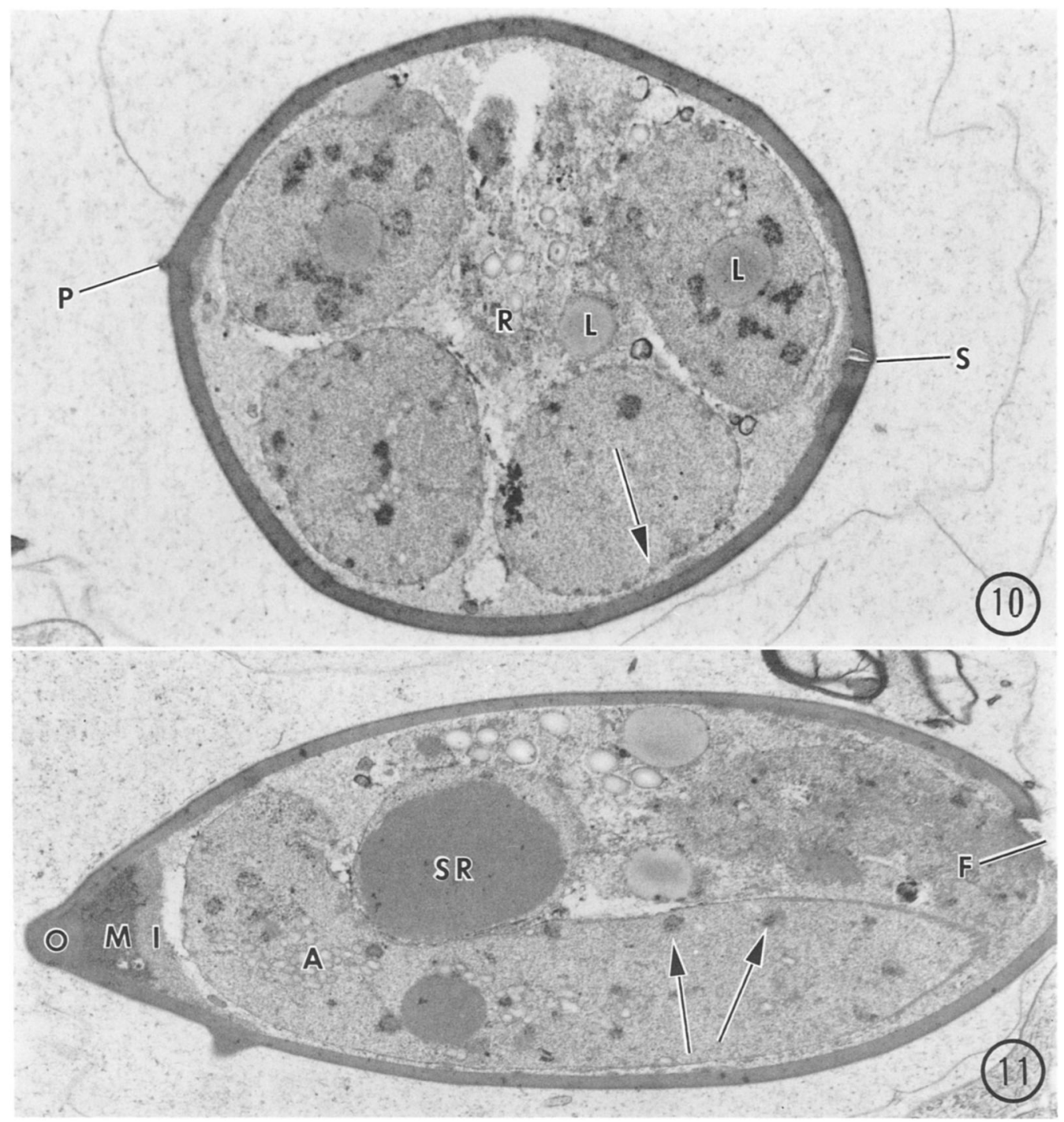

Figures 10,11. Eimeria funduli. 10. Diagonal section of sporocyst with the two sporozoites each cut in two sections. Note suture (S) with intervening dense material on one side of oocyst wall and papillalike projection (P) on opposite side. Subpellicular microtubules (arrow), sporocyst residuum (R), lipoid bodies (L). $\times 19,700$. 11. Posterior pole of sporocyst is pointed in longitudinal sections perpendicular to the fissure. Three layers make up this region of sporocyst: an outer thickening of the sporocyst wall $(\mathrm{O})$, a middle electron-dense layer $(\mathrm{M})$, and an inner electron-lucent area (I). Sporocyst refractile body (SR), amylopectin (A), fissure (F), foci of ribosomelike granules (arrows). $\times 16,400$.

and there were no anlagen of rhoptries or micronemes. Sporozoites had a conoid and an anterior polar ring system, numerous small amylopectin (polysaccharide) granules (about $90 \mathrm{~nm}$ diameter) (Fig. 11), a few lipidlike bodies (about $0.4 \mu \mathrm{m}$ diameter), and a large (about $2 \mu \mathrm{m}$ diameter) refractile body (Figs. 8, 11, 12, 13). Foci of ribosomelike granules occurred throughout the sporozoite (Fig. 11). Cross-sections of sporo- zoites showed approximately 32 subpellicular microtubules (Fig. 10). In addition to the two sporozoites, some sporocysts contained residual material consisting of lipidlike bodies and amylopectin granules (Fig. 11).

\section{DISCUSSION}

Few detailed studies on coccidian oocysts were available before Birch-Andersen et al. (1976) in- 


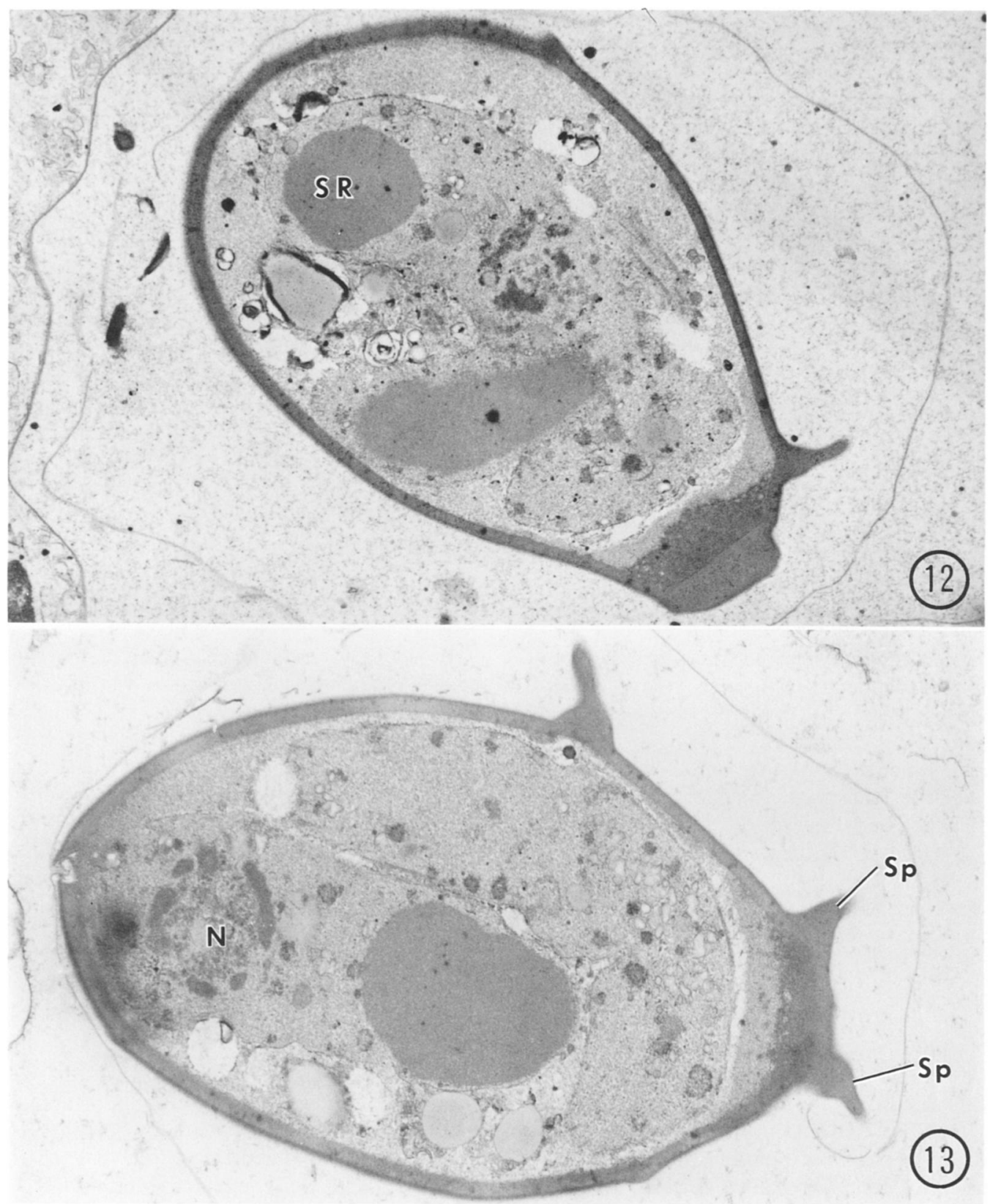

Figures 12, 13. Eimeria funduli. 12. Knoblike appearance of posterior pole of sporocyst in sections parallel to the fissure. Sporocyst refractile body (SR). $\times 15,500$. 13. Knoblike posterior pole in longitudinal section through sporocyst parallel to fissure. Note sporopodia $(\mathrm{Sp})$ at each end of ridge. Sporozoite nucleus $(\mathrm{N}) . \times 18,700$.

troduced a cryo-processing technique in which isolated oocysts are embedded in cross-linked bovine serum albumin, cryostat-sectioned, fixed in glutaraldehyde, and embedded in epoxy resin for routine TEM. Whether the simpler technique used in the present study will be useful if applied to thick-walled coccidian oocysts in terrestrial hosts remains to be determined.

Some findings in the present study do not agree with those of Duszynski et al. (1979) who examined oocysts of $E$. funduli isolated by sugar flotation from homogenized tissues. Apparently, 
most of the discrepancies in the two studies, as discussed below, result from differences in methods of preparation.

The oocyst wall of $E$. funduli consists of two unit membranes separated by a narrow space and possibly some electron-dense material that lines the inner membrane. Ultrastructurally-similar oocyst walls consisting of one or two unit membranes have been reported in the piscine eimerians Goussia degiustii (Molnár and Fernando, 1974) by Lom (1971, reported as E. spleni), G. gadi (Fiebiger, 1913) by Odense and Logan (1976), and E. variabilis (Thélohan, 1893) by Davies (1978). Oocyst walls in most coccidia having terrestrial hosts have one to three layers and form from deposition of wall-forming bodies at the limiting membrane of the macrogamont or zygote (reviewed by Speer et al., 1979). The oocyst wall in E. funduli, and probably other piscine coccidia possibly is not equivalent to that of coccidia that infect terrestrial hosts because it lies adjacent to the host cell and part of it appears to some investigators as the limiting membrane of the host cell cytoplasm. Structures resembling wall-forming bodies in $E$. funduli macrogamonts (Hawkins et al., 1983a) are either vestigial or function in some other manner, possibly in the formation of the sporocyst wall or the thin layer of electron-dense material that lines the inner membrane of the oocyst wall. Dyková and Lom (1981) suggested that oocyst walls in piscine coccidians are remnants of the limiting membrane of the macrogamont. This is probably not true in E. funduli. Macrogamonts (Hawkins et al., 1983a), microgamonts (Hawkins et al., 1983b), and other developmental stages (preliminary observations) of $E$. funduli are all situated in a parasitophorous vacuole limited by a cisterna of rough endoplasmic reticulum that apparently develops from host membranes. Because of the location and organization of the oocyst wall in $E$. funduli, the limiting membranes of the parasitophorous vacuole probably become the oocyst wall. Lom (1971) suggested that the oocyst walls in fish coccidia need not be thick because the aquatic environment protects the oocyst from mechanical damage and desiccation. In preliminary studies, the oocyst wall of $E$. funduli appears remarkably strong in spite of its thinness. In fact, it remains intact for at least $12 \mathrm{hr}$ in the gastric mill of its intermediate host, Palaemonetes pugio.

Two primary types of sporocyst walls occur in coccidians. One type, represented in sporocysts of species in the genus Eimeria Schneider, 1875 , has a single polar opening plugged by a Stieda body and an associated subStieda body (Roberts et al., 1970). Excystation occurs when digestive fluids dissolve the Stieda and subStieda bodies, allowing the sporozoites to escape (Roberts et al., 1970). The other type of wall, represented in some members of the genus Isospora Schneider, 1881 (see Speer et al., 1973; Speer et al., 1976) and by Toxoplasma gondii (Nicolle and Manceaux, 1908) (see Ferguson et al., 1979b) consists of two layers, the inner of which is comprised of up to four separate plates. Digestive juices act on material at the sites of apposition of the plates, causing the plates to separate and release the sporozoites (Ferguson et al., 1979a; Speer et al., 1973; Speer et al., 1976). The mechanism for excystation in $E$. funduli must differ from either of these because the sporocyst does not have a Stieda body and the sporocyst wall does not consist of joined plates although some dense material that originates from sporocyst contents occurs in the gap near its posterior extent.

The sporocyst wall of $E$. funduli apparently consists of a single shell, or valve, with a thickening at one end and a narrow fissure bridged by the membranous veil at the other end. The Stiedalike thickening in $E$. funduli cannot be considered a true Stieda body as suggested by Duszynski et al. (1979) because it does not close an opening in the sporocyst wall. Dyková and Lom (1981) proposed that piscine coccidians be classified according to, among other characteristics, the organization of the sporocyst wall. They placed species in which sporocysts lack a Stieda body and have a wall consisting of two valves joined along a meridional suture within the genus Goussia Labbé, 1896. The three piscine coccidians, E. variabilis, G. gadi, and G. degiustii, that have been studied ultrastructurally generally conform to these characteristics. In E. variabilis, Davies (1978) identified Stieda bodies by light microscopy and attributed their absence in TEM preparations to the early developmental stage of the examined sporocysts. However, the TEM micrograph by Davies showed sporocyst walls to have a short papillalike projection similar to the one that occurs where the lips of the fissure in the sporocyst wall of $E$. funduli join. Therefore, the possibility exists that the Stiedalike body seen with LM in $E$. variabilis is actually similar to the posteriorly-located structure in E. funduli. Neither Stieda nor Stiedalike bodies were reported in sporocysts of $G$. gadi by Odense and Logan 
(1976) or in sporocysts of $G$. degiustii by Lom (1971). Sporocyst walls in both $G$. gadi and $G$. degiustii have fissures that might completely separate those sporocysts into two valves, although a scanning electron micrograph of $G$. gadi by Odense and Logan (1976) showed what might be a sporocyst with incompletely-separated valves and thus similar to the sporocyst of $E$. funduli. The sporocyst wall of $G$. gadi has a transverse periodic substructure similar to that in $E$. fun$d u l i$, but its substructure in $G$. gadi was interrupted by fracture lines. Lom (1971) reported that $G$. degiustii had a "membranaceous collar" that attached to the sporocyst wall along the suture line similar to the attachment of the veil along the fissure in the sporocyst wall in $E$. fun$d u l i$. Once the oocyst wall of $E$. funduli becomes disrupted in its intermediate host, the membranous veil appears to be the only structure retaining the sporozoites in the sporocyst. This membrane in $E$. funduli and $G$. degiustii might correspond to the outer, double-membrane layer of the sporocyst wall which is derived from the limiting membranes of the sporoblast in coccidia with terrestrial hosts such as Toxoplasma gondii (see Ferguson et al., 1979b).

In any event, until the genus Goussia is reviewed adequately, with a type-species established, its status will be uncertain. That review should include ultrastructural aspects of the sporocysts of some, if not all, the nominal species.

\section{ACKNOWLEDGMENTS}

We thank Mrs. Eve Wells and Mr. Robert J. Allen for their technical assistance. This study was conducted in cooperation with the U.S. Department of Commerce, NOAA, National Marine Fisheries Service, under PL 88-309 Project No. 2-382-R.

\section{LITERATURE CITED}

Birch-Andersen, A., D. J. P. Ferguson, ANd R. D. Pontefract. 1976. A technique for obtaining thin sections of coccidian oocysts. Acta Path. Microbiol. Scand. Sect. B 84: 235-239.

DAvies, A. J. 1978. Coccidian parasites of intertidal fishes from Wales: Systematics, development, and cytochemistry. J. Protozool. 25: 15-21.
Desser, S. S. 1981. The challenge of fish coccidia. J. Protozool. 28: 260-261.

Duszynski, D. W., M. A. Solangi, and R. M. OverSTREET. 1979. A new and unusual eimerian (Protozoa: Eimeriidae) from the liver of the Gulf killifish, Fundulus grandis. J. Wildl. Dis. 15: 543552.

DYKovÁ, I., AND J. LoM. 1981. Fish coccidia: critical notes on life cycles, classification and pathogenicity. J. Fish Dis. 4: 487-505.

Ferguson, D. J. P., A. Birch-Andersen, J. C. Siim, AND W. M. Hutchison. 1979a. An ultrastructural study on the excystation of the sporozoites of Toxoplasma gondii. Acta Path. Microbiol. Scand. Sect. B 87: 227-283. - AND 1979b. Ultrastructural studies on the sporulation of oocysts of Toxoplasma gondii. II. Formation of the sporocyst and structure of the sporocyst wall. Acta Path. Microbiol. Scand. Sect. B 87: 183-190.

Hawkins, W. E., M. A. Solangi, and R. M. OverSTREET. 1983a. Ultrastructure of the macrogamont of Eimeria funduli, a coccidium parasitizing killifishes. J. Fish Dis. 6: 33-43.

$\longrightarrow,-$ AND $\longrightarrow$ 1983b. Ultrastructure of the microgamont and microgamete of Eimeria funduli, a coccidium parasitizing killifishes. J. Fish Dis. 6: 45-57.

LoM, J. 1971. Remarks on the spore envelopes in fish coccidia. Folia Parasitol. (Prague) 18: 289293.

Odense, P. H., and V. H. Logan. 1976. Prevalence and morphology of Eimeria gadi (Fiebiger, 1913) in the haddock. J. Protozool. 23: 564-571.

Overstreet, R. M. 1981. Species of Eimeria in nonepithelial sites. J. Protozool. 28: 258-260.

Roberts, W. L., C. A. Speer, AND D. M. Hammond. 1970. Electron and light microscopic studies of the oocyst walls, sporocysts, and excysting sporozoites of Eimeria callospermophili and E. larimerensis. J. Parasitol. 56: 918-926.

Solangi, M. A., AND R. M. Overstreet. 1980. Biology and pathogenesis of the coccidium Eimeria funduli infecting killifishes. J. Parasitol. 66: 513526.

SPeer, C. A., D. M. Hammond, J. L. Mahrt, AND W. L. ROBERTS. 1973. Structure of the oocyst and sporocyst walls and excystation of sporozoites of Isospora canis. J. Parasitol. 59: 35-40.

- A. A. Marchiondo, D. W. DuSZYNSKI, AND S. K. FILE. 1976. Ultrastructure of the sporocyst wall during excystation of Isospora endocallimici. J. Parasitol. 62: 984-987.

- - B. MuelleR, AND D. W. DuszYNSKI. 1979. Scanning and transmission electron microscopy of the oocyst wall of Isospora lacazei. Z. Parasitenkd. 59: 219-225. 